\title{
Occipital Condyle Syndrome as the First Sign of Metastatic Cancer
}

\author{
Jeremy J Moeller, Sudeep Shivakumar, Mary Davis, Charles E Maxner
}

\begin{abstract}
Background: Occipital condyle syndrome is characterized by severe, unilateral, occipital headache and ipsilateral twelfth-nerve palsy. It is associated with skull-base metastasis. Cases: We identified two patients with sub-acute onset of severe, unilateral, occipital headache and ipsilateral tongue paralysis. The first patient was a 58-year-old woman with a history of limited stage small-cell lung cancer in clinical remission. The second patient was an otherwise healthy 36-year-old man. Neither patient had any other findings on general medical or neurological examination. One patient had only equivocal findings on initial magnetic resonance imaging (MRI), and the other patient's MRI was normal. Although initial work-up for metastatic disease was normal, the first patient developed severe bone pain over the next few months, and follow-up investigations demonstrated metastases to her spine, tibia, skull base and brain. The second patient improved initially, but was admitted to hospital three months later with constitutional symptoms and pancytopenia. Bone marrow and lymph node biopsies were consistent with Stage IVB Hodgkin's lymphoma. Conclusion: Occipital condyle syndrome can be the first presentation of disseminated malignancy. Initial imaging of the brain and skull base may be normal, and recognition of this syndrome warrants thorough investigation and close follow-up.
\end{abstract}

RÉSUMÉ: Syndrome du condyle de l'occipital comme signe d'appel d'un cancer métastatique. Contexte : Le syndrome du condyle de l'occipital se caractérise par une céphalée occipitale unilatérale sévère et une paralysie ipsilatérale du douzième nerf crânien. Ce syndrome est associé à une néoplasie avec métastase à la base du crâne. Description de cas : Nous avons identifié deux patients ayant présenté une céphalée occipitale unilatérale sévère à début sub-aigu et une paralysie ipsilatérale de la langue. Le premier patient était une femme de 58 ans qui avait été atteinte d'un cancer du poumon à petites cellules au stade limité, en rémission clinique. Le second patient était un homme de 36 ans en bonne santé par ailleurs. On n'a rien trouvé d'autre chez ces deux patients à l'examen général ou à l'examen neurologique. L'imagerie par résonance magnétique (IRM) initiale était équivoque chez un patient et normale chez le second. Bien que le bilan initial pour détecter des métastases ait été normal, la première patiente a présenté des douleurs osseuses sévères dans les mois qui ont suivi et on a alors constaté la présence de métastases à la colonne vertébrale, au tibia, à la base du crâne et au cerveau. L'état du second patient s'est d'abord amélioré, mais il a dû être hospitalisé trois mois plus tard pour des symptômes généraux et une pancytopénie. Des biopsies de la moelle osseuse et de ganglions lymphatiques ont révélé la présence d'un lymphome de Hodgkin de stade IVB. Conclusion : Le syndrome du condyle de l'occipital peut être le signe d'appel d'un cancer métastatique. L'imagerie du cerveau et de la base du crâne peut être normale initialement. En présence de ce syndrome, on doit procéder à un bilan rigoureux et assurer un suivi étroit par la suite.

Can. J. Neurol. Sci. 2007; 34: 456-459

Metastasis to the base of the skull can result in a variety of clinical presentations. In 1981, Greenberg et $\mathrm{al}^{1}$ evaluated 43 patients with skull base metastases, and described five distinct clinical syndromes: the orbital, parasellar, middle fossa, jugular foramen, and occipital condyle syndromes. Of these, the occipital condyle syndrome (OCS) was associated with the most clearly stereotyped clinical presentation. Patients with OCS presented with a severe, continuous, unilateral occipital headache, often exacerbated by head-turning. Physical findings were usually limited to a unilateral hypoglossal paresis and mastoid tenderness.

We present two cases of typical OCS, both of which were the first sign of disseminated malignancy. The challenges in establishing the diagnosis of disseminated malignancy will be discussed.
From the Division of Neurology (JJM, CEM), Division of Haematology (SS), Division of Medical Oncology (MD), Department of Medicine, Dalhousie University and Capital District Health Authority, Halifax, Nova Scotia, Canada ReCEIVEd APRIL 5, 2007. ACCEPTEd IN FinAl fORm July 3, 2007. Reprint requests to: Charles E Maxner, Division of Neurology, Department of Medicine, Queen Elizabeth II Health Sciences Centre, 1796 Summer Street, Halifax, Nova Scotia, B3H 3A7, Canada. 


\section{Patient 1}

A 58-year-old woman presented to the emergency department with a six-week history of severe, constant, left-sided headache. The pain originated in the left occipital region and radiated over the top of her head. Three weeks after the onset of her headache, she experienced sudden onset dysarthria and tongue weakness. She had no other symptoms, and was feeling otherwise well.

She had a past history of small cell lung cancer, which had been diagnosed a year previously. She had been treated with radiotherapy and etoposide/carboplatin chemotherapy. Her last cycle of chemotherapy was approximately six months prior to the onset of her headache, and she had no symptoms of recurrence. She also had a past history of migraine without aura.

Her general medical examination was normal, with the exception of tenderness over her left mastoid region. The sole abnormality on neurological examination was left tongue deviation and significant left-sided tongue atrophy (Figure 1).

A standard computed tomography (CT) scan of her head was normal. Cerebrospinal fluid studies, including cytological examination, were normal. Magnetic resonance imaging (MRI) of her brain showed no enhancing lesions and no stroke. Magnetic resonance angiography (MRA) was normal. Note was made of a minor hypointensity in the marrow of the left occipital condyle (Figure 2A and 2B). Subsequent bone scan did not demonstrate any abnormality in the skull base.

After a week, she began to develop severe low back pain and bony tenderness in the sacro-iliac area bilaterally. Magnetic resonance imaging of her spine demonstrated an epidural mass

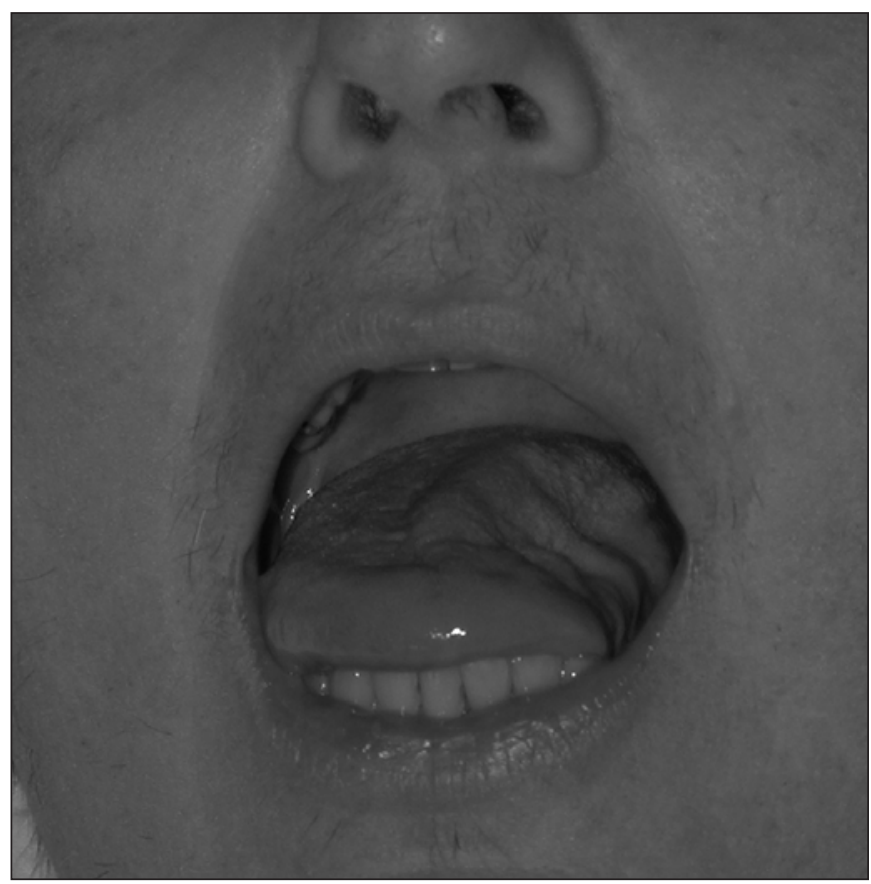

Figure 1: Photograph of patient 1 demonstrating unilateral tongue atrophy on the left side. and marrow infiltration of the vertebral bodies at several levels. She was re-admitted to hospital and a diagnosis of metastases from lung cancer was made. She was treated with palliative radiotherapy. A few weeks later, she developed diplopia, and physical examination demonstrated a partial left sixth nerve palsy. Repeat MRI of her head demonstrated a large skull base mass that extended from the left occipital condyle into the clivus and left sphenoid sinus (Figure 2C and 2D). There were also two new enhancing lesions in the right frontal lobe.

As she had not responded to radiotherapy, her care was
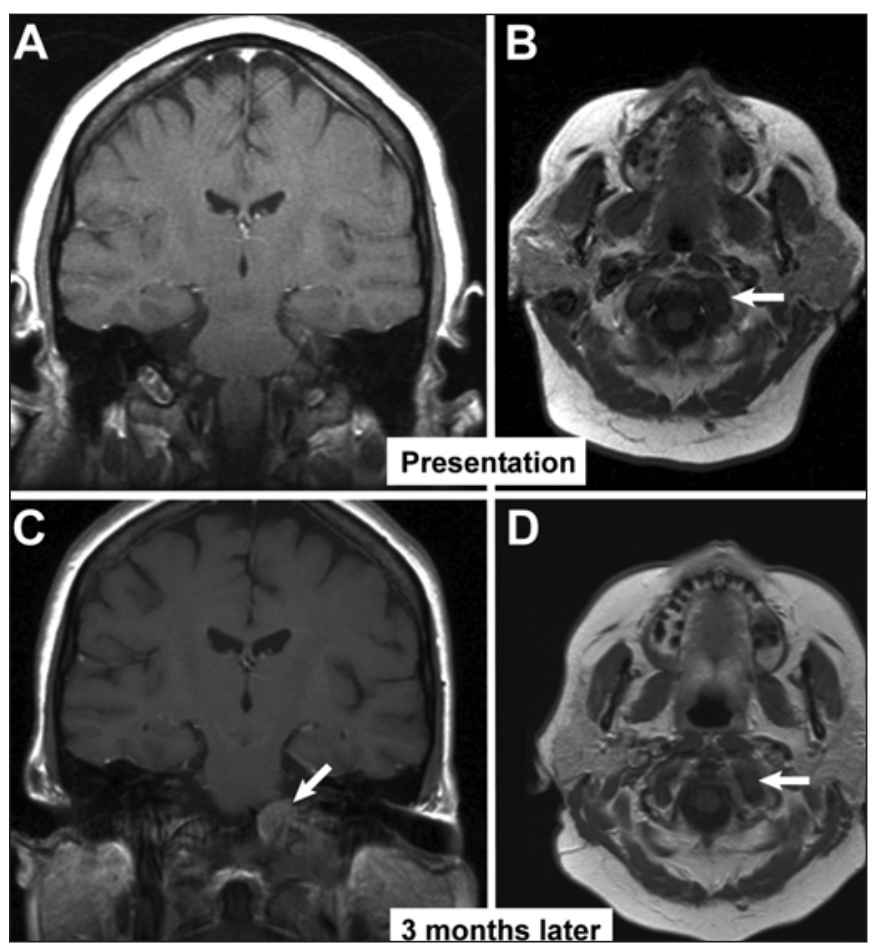

Figure 2: Diagnostic images of Patient 1. A and C are coronal T1weighted MR images after gadolinium enhancement. A was taken at the time of initial presentation, and shows no abnormality. $C$ was taken three months after initial presentation, and shows a mass extending from the left clivus and occipital condyle into the epidural space adjacent to the pons (arrow). B and D are axial T1-weighted MR images without contrast enhancement. $B$ was taken at presentation and demonstrates a subtle decrease in signal in the left occipital condyle (arrow). D was taken three months after initial presentation and shows the same changes (arrow).

transferred to the palliative care service. She was treated with oral dexamethasone and analgesics, and died at home five months after the onset of her tongue weakness.

\section{Patient 2}

This 36-year-old man presented to the emergency department with a ten-day history of severe, sharp headache in the left 
occipital region. The pain originated in the left side of his neck and radiated through the mastoid region to the top of his head. It was so intense that it interfered with his sleep. Two days after the onset of his headache, he noticed mild dysarthria and difficulty chewing certain foods. Six weeks prior to the onset of his headache, he had right facial numbness and paresthesias that had resolved spontaneously after two weeks. He was otherwise well and had no relevant past medical history.

There were no abnormalities on general medical examination. The only abnormality on neurological examination was leftward deviation of his tongue and left-sided tongue weakness. There was no tongue atrophy.

Computed tomography of his head demonstrated a subtle hyperdensity in the region of the right cavernous sinus. However, subsequent magnetic resonance imaging did not reveal any abnormality in this region. There were no soft tissue masses or posterior fossa lesions on MRI, and magnetic resonance angiography was normal.

Although this patient received no treatment, the headache and tongue weakness gradually resolved over the next few weeks. However, two months later, he developed severe nausea and vomiting and a diffuse headache. He also started to experience intermittent chills and severe drenching night sweats. Laboratory investigations showed pancytopenia, with a white blood cell count of 2,600 x 106/L, hemoglobin of $131 \mathrm{~g} / \mathrm{L}$ and a platelet count of $139,000 \times 10^{6} / \mathrm{L}$. His serum calcium level was elevated at $3.35 \mathrm{mmol} / \mathrm{L}$. Chest radiograph showed a paravertebral mass at the T10 level.

He was admitted to hospital for medical management and further investigations. Computed tomography of his chest, abdomen and pelvis confirmed the presence of a paravertebral mass at the T10 level. In addition, there was mild splenomegaly, multiple enlarged para-aortic and retroperitoneal lymph nodes and two pulmonary nodules in the left lower lobe. Bone marrow biopsy showed hypercellular marrow with many Reed-Sternberg cells and an immunohistochemical pattern consistent with Hodgkin's lymphoma. A CT-guided biopsy of a retroperitoneal lymph node confirmed the diagnosis of Hodgkin's lymphoma.

Because of the bone marrow involvement and constitutional symptoms, it was determined that he had Stage IVB disease. He was treated with six cycles of ABVD (doxorubicin, bleomycin, vinblastine and dacarbazine) chemotherapy, and initially showed signs of remission. However, he has since returned with recurrent disease, is being treated with salvage chemotherapy. $\mathrm{He}$ is being evaluated for bone marrow or peripheral blood stem cell transplantation.

\section{DisCUSSION}

Both of these cases demonstrate several key features of occipital condyle syndrome. In our patients, and in almost all of the 25 previously-reported cases of OCS, ${ }^{1,4}$ there was a stereotyped pattern of severe, continuous, unilateral headache and associated mastoid tenderness (Table). Almost all patients had isolated unilateral tongue paresis with no other abnormalities on neurological examination. In most of these cases, headache preceded the tongue paresis, often by days or weeks.

As with our patients, diagnosing the underlying cause of occipital condyle syndrome can be challenging. It is difficult to establish the utility of cytological examination of the cerebrospinal fluid, as it is reported in only three cases. However, in all three cases, it was negative. Imaging techniques such as computed tomography (CT) of the skull base and radionucleotide bone scan often do not demonstrate abnormalities in the occipital condyle. As seen in the Table, magnetic resonance imaging (MRI) is more sensitive in detecting abnormalities in the occipital condyle. However, this test is also imperfect. In one of our patients, and in one

Table: Summary of the clinical characteristics of all reported cases of occipital condyle syndrome

\begin{tabular}{|c|c|c|c|c|c|c|c|c|c|c|c|c|c|}
\hline Study & $\begin{array}{c}\begin{array}{c}\text { Number } \\
\text { of } \\
\text { patients }\end{array}\end{array}$ & $\begin{array}{l}\text { Age } \\
\text { (yrs) }\end{array}$ & $\begin{array}{c}\text { Severe, } \\
\text { continous } \\
\text { unilateral } \\
\text { headache }\end{array}$ & $\begin{array}{c}\text { Mastoid } \\
\text { tenderness }\end{array}$ & $\begin{array}{l}\text { Isolated CN } \\
\text { XII palsy on } \\
\text { exam }\end{array}$ & $\begin{array}{l}\text { Headache } \\
\text { preceded } \\
\text { tongue } \\
\text { paresis }\end{array}$ & $\begin{array}{l}\text { Time to } \\
\text { diagnosis } \\
\text { (from } \\
\text { symptom } \\
\text { onset) }\end{array}$ & $\begin{array}{l}\text { CSF } \\
\text { cytology } \\
\text { positive }\end{array}$ & $\begin{array}{l}\text { Bone } \\
\text { scan } \\
\text { positive }\end{array}$ & $\begin{array}{l}\text { Initial CT } \\
\text { abnormal }\end{array}$ & $\begin{array}{l}\text { Initial MRI } \\
\text { abnormal }\end{array}$ & $\begin{array}{c}\text { No Prior } \\
\text { history of } \\
\text { cancer } \\
\text { (i.e. first } \\
\text { presentation) }\end{array}$ & $\begin{array}{l}\text { Presumed primary } \\
\text { malignancy }\end{array}$ \\
\hline $\begin{array}{l}\text { Greenberg et } \\
\text { al, } 1981 \text { [1] }\end{array}$ & 9 & $N R$ & $7 / 9$ & $9 / 9$ & $6 / 9^{*}$ & $N R$ & $2-6$ weeks & $N R$ & $N R$ & $2 / 3^{*}$ & $N R$ & $1 / 9$ & $\begin{array}{l}\text { Breast (4), Lung (1), } \\
\text { Prostate (1), } \\
\text { Lymphoma (1), } \\
\text { Other (2) }\end{array}$ \\
\hline $\begin{array}{l}\text { Moris et al., } \\
1998 \text { [2] }\end{array}$ & 4 & $48-77$ & $4 / 4$ & $3 / 4$ & $4 / 4$ & $3 / 4$ & $\begin{array}{l}1 \text { week - } \\
3 \text { months }\end{array}$ & $N R$ & $2 / 3^{*}$ & $4 / 4$ & $1 / 2^{\star}$ & $4 / 4$ & $\begin{array}{l}\text { Prostate (1), } \\
\text { Nasopharyngeal (1), } \\
\text { Fibrosing } \\
\text { psuedotumour (1), } \\
\text { Unknown (1) }\end{array}$ \\
\hline $\begin{array}{l}\text { Capobianco et } \\
\text { al., } 2002 \text { [3] }\end{array}$ & 11 & $32-72$ & $8 / 8^{*}$ & $10 / 10^{*}$ & $11 / 11$ & $7 / 9^{*}$ & $\begin{array}{c}0-10 \\
\text { weeks }\end{array}$ & $0 / 2^{*}$ & $7 / 10^{*}$ & $4 / 7^{\star}$ & $7 / 7^{\star}$ & $2 / 11$ & $\begin{array}{l}\text { Prostate (4), Breast } \\
\text { (2), Bowel (2), } \\
\text { Other/Unknown (3) }\end{array}$ \\
\hline $\begin{array}{l}\text { Salamanca et } \\
\text { al., } 2006[4]\end{array}$ & 1 & 66 & $1 / 1$ & $1 / 1$ & $1 / 1$ & $1 / 1$ & 3 weeks & $N R$ & $0 / 1$ & $1 / 1$ & $1 / 1$ & $1 / 1$ & Prostate \\
\hline Our cases & 2 & $36-58$ & $2 / 2$ & $2 / 2$ & $2 / 2$ & $2 / 2$ & 1-3 months & $0 / 1^{*}$ & $0 / 1^{*}$ & $0 / 2$ & $1 / 2$ & $1 / 2$ & Lung (1), Hodgkin's \\
\hline Total & 27 & $32-77$ & $22 / 24$ & $25 / 26$ & $24 / 27$ & $13 / 16$ & $0-3$ months & $0 / 3$ & $9 / 15$ & $11 / 17$ & $10 / 12$ & $9 / 27$ & \\
\hline
\end{tabular}

*Information was not available for all cases, therefore, only reported information is shown 
previously-reported case, ${ }^{2}$ there was no abnormality of the skull base on MRI. Presumably, a very small space-occupying lesion (too small to be detected by conventional imaging) can be sufficient to cause headache and hypoglossal palsy. Importantly, evaluation of the occipital condyles (on imaging) by a radiologist can be hampered by insufficient clinical data. ${ }^{5}$

There is no obvious explanation as to why Patient 2 improved spontaneously before returning with constitutional symptoms and lymphadenopathy. There are case reports of spontaneous remission of Hodgkin's lymphoma,${ }^{6}$ which is presumed to be on the basis of an immune response, though other factors have been implicated. It is conceivable that a small occipital condyle tumour could remit spontaneously, even as the lymphoma continued to proliferate elsewhere.

Occipital condyle syndrome was the first manifestation of malignancy in Patient 2, and in 8 of 25 previously-reported cases. The diagnosis of malignancy is frequently delayed by several months. A wide variety of malignancies can cause OCS, including metastases from solid tumours of the breast, lung, prostate and gastrointestinal tract, primary pharyngeal tumours and lymphoma. Only a small fraction of patients with OCS have a benign explanation for their symptoms. In a series of 100 patients with twelfth nerve palsy, over half of patients with nontraumatic tongue paresis had a malignancy. ${ }^{7}$
In summary, occipital condyle syndrome is a rare but easily recognizable and clearly stereotyped clinical syndrome that is usually associated with skull-base metastasis. The diagnosis can be elusive, and diagnostic imaging of the skull base may be normal on initial presentation. Patients who present with this syndrome should be evaluated carefully to rule out malignancy.

\section{REFERENCES}

1. Greenberg HS, Deck MDF, Vickram B, Chu FCH, Posner JB. Metastasis to the base of the skull: clinical findings in 43 patients. Neurology. 1981;31:530-7.

2. Moris G, Roig C, Misiego M, Alvarez A, Berciano J, Pascual J. The distinctive headache of the occipital condyle syndrome: a report of four cases. Headache. 1998;38:308-11.

3. Capobianco DJ, Brazis PW, Rubino FA, Dalton JN. Occipital condyle syndrome. Headache. 2002;42:142-6.

4. Salamanca JIM, Murrieta C, Jara J, Munoz-Blanco JL, Alvarez F, de Villoria JG, et al. Occipital condyle syndrome guiding diagnosis to metastatic prostate cancer. Int J Urology. 2006;13: $1022-4$.

5. Loevner L, Yousem DM. Overlooked metastatic lesions of the occipital condyle: a missed case treasure trove. RadioGraphics. 1997; 17:1111-21.

6. Mangel J, Brath D, MacEachren J, Berinstein NL, Imrie KR. Spontaneous regression of Hodgkin's disease: two case reports and a review of the literature. Hematology. 2003;8:191-6.

7. Keane JR. Twelfth-nerve palsy. Analysis of 100 cases. Arch Neurol. 1996;53:561-6. 